\title{
End users' purchasing task involvement, power and influence strategies in organizational buying
}

\section{Pedeliento, Giuseppe}

2019

Pedeliento , G , Andreini , D , Bergamaschi , M \& Salo , J 2019 , ' End users' purchasing task involvement, power and influence strategies in organizational buying ' , Journal of Business and Industrial Marketing , vol. 34 , no. 1 , pp. 150-165 . https://doi.org/10.1108/JBIM-01-2018-0037

http://hdl.handle.net/10138/321709

https://doi.org/10.1108/JBIM-01-2018-0037

acceptedVersion

Downloaded from Helda, University of Helsinki institutional repository.

This is an electronic reprint of the original article.

This reprint may differ from the original in pagination and typographic detail.

Please cite the original version. 


\title{
End Users' Purchasing Task Involvement, Power, and Influence Strategies in Organizational Buying
}

\begin{abstract}
Purpose - To explore the motives behind end users' influence in purchasing, and the way in which such influence manifests. The research draws on the concept of purchasing task involvement to gain a deeper understanding of users' stakes in organizational purchasing and links it to sources of power and corresponding influence strategies deployed.

Design/methodology/approach - The research is based on 90 in-depth interviews with buyers, drivers and sellers of heavy trucks.

Findings - Purchasing task involvement largely extends the technical products' and brands' features. Users' involvement in the purchasing decision is common among end users, but relates to manifest influence under specific contingencies and specific distributions of power between the buyer and the user. Users were found to rely on reinforcement and referent power, while buyers, in turn, on legitimate or expert power to avoid users influencing buying decisions, or on reinforcement power to allow their participation.
\end{abstract}

Originality/value - This is the first study to link end users' purchasing task involvement, power, and influence strategies in organizational buying.

Keywords: users; purchasing task involvement; power; influence strategies; organizational buying processes; trucks

Article Classification: research paper 


\section{Introduction}

Although the literature abounds in studies aimed at analyzing the influential role that purchasing agents play in organizational buying processes, studies that focus on end usersi.e. those organizational actors who use the product once purchased-are in comparatively shorter offer (Silk and Kalwani, 1982; Lewin and Donthu, 2005; Howard and Doyle, 2006; Celuch et al., 2007). Existing research reveals three main findings and two main gaps about end users' influence in organizational purchasing. As far as findings are concerned, the first is that users' influence depends upon the level of novelty, complexity, and importance implied in the product to purchase (Robinson et al., 1967; Grønhaug, 1976; Jackson et al., 1984; Moriarty and Spekman, 1984; McQuiston, 1989; Qualls and Rosa, 1995; Kauffman, 1996; Moon and Tikoo, 2002; Harrington and Tjan, 2008). Second, end users' influence varies throughout the different phases of the purchasing process (Johnston and Bonoma, 1981; Lilien and Wong, 1984; Naumann et al., 1984; Dadzie et al., 1999; Garrido-Samaniego and Gutierrez-Cillan, 2004). Users are generally more influential in earlier phases, while their influence wanes as the decision process continues (Berkowitz, 1986). Third, the main reason that end users are keen to take part in organizational buying processes is their willingness to obtain specific products or specific product features that allow them to better perform their job (Sheth, 1973; Harrington and Tjan, 2008).

Concerning the gaps, the first regards the motives prompting users' participation in organizational purchasing (Gilliland and Johnston, 1997; Wilson, 2000; Pedeliento et al., 2016). Scholars have found that when the product to be purchased is employed by end users on a daily basis (implying a high level of object-subject interaction), users have a higher level of purchasing task involvement compared to other purchases in which this interaction is less significant (Bonoma, 1982; Gilliland and Johnston, 1997; Harrington and Tjan, 2008; Töllner et al., 2011). Purchasing task involvement is defined as the feelings of personal relevance that a buying center member experiences toward the purchase of a specific product (Gilliland and Johnston, 1997). These feelings of personal relevance do not necessarily relate to technical product features and to its performances, but can encompass ego-related product meanings and personal goals and values (Gilliand and Johnston, 1997), emotion and self-expressive benefits (Mudambi, 2002), affection (Erevelles, 1998; Wilson, 2000; Pedeliento et al., 2016), and other feelings stemming from product usage. Yet, to date, we still have limited knowledge both of the existence of these feelings of users' relevance and of the impact (if any) of this personal relevance on the buying decision. 
In addition, a further gap is identified and deals with the nature of power held by end users and the influence strategies they deploy to affect purchasing choices. Previous studies on power in organizational purchases (Kohli, 1989; Venkatesh et al., 1995; Farrell and Schroder, 1999) have focused on purchasing agents, and little is said about end users as both sources or targets of influence strategies pursued by other members of the organizational buying center. Users are in fact often considered volunteer participants in buying processes rather than legitimate influencers (Tanner, 1998).

In light of these gaps, the aim of this study is twofold. First aim is to investigate the influence of end users in organizational buying processes in a purchasing context characterized by a high level of purchasing task involvement for the user (Gilliland and Johnston 1997). Second aim is to shed light on the bases of power (French and Raven, 1959; Kohli, 1989) and the influence strategies deployed by end users (Venkatesh et al., 1995; Farrell and Schroder, 1999) in such purchasing context

To reach these objectives, we focused on the purchasing process for new heavy trucks. The research adopts a qualitative approach consisting of in-depth interviews with multiple informants, namely buyers (mostly company owners), end users (i.e. truck drivers) and sales people working for truck dealers. The remainder of this research is structured as follow. First, we review the relevant literature concerning end users' influence in organizational buying processes. Second, we review the concepts of power and power strategies. Third, the research methodology is described, and the main findings are shown and discussed. Finally, conclusions, managerial implications, limitations, and directions for future research are provided.

\section{The role of end users in organizational buying processes}

Research on individuals' influences in organizational buying processes constitutes the biggest block of studies in the stream of organizational buying behavior (Kauffman, 1996; Chandler and Johnston, 2012). However, works dealing with the role played by end users are in short offer if compared with the number of research focusing on purchasing agents (see Appendix A).

As identified by Celuch et al. (2007), industrial manufacturers often lack or have very limited knowledge of their end users, although they have a vital influence on what the organization decides to purchase. 
The prevailing view in the literature is that users' influence on organizational buying depends on the type of product being purchased. Users are found to be active participants in purchasing processes when the product to purchase has a high level of novelty, complexity, and importance to the purchasing organization (Robinson et al., 1967; Grønhaug, 1976; Jackson et al., 1984; Moriarty and Spekman, 1984; McQuiston, 1989; Qualls and Rosa, 1995; Kauffman, 1996; Moon and Tikoo, 2002; Harrington and Tjan, 2008). Studies have also shown that end users are more likely than non-users to initiate the purchase and that their influence wanes in further stages of the decision process (Berkowitz, 1986). Scholars also suggest that end users are keener to participate in the purchasing process to obtain certain product specifications and performances that can help them to better perform their job (Berkowitz, 1986; Tanner, 1998; Harrington and Tjan, 2008; Töllner et al., 2011). Accordingly, it is generally assumed that end users look for prompt delivery, proper installation, efficient serviceability, and effective deployment of the solution (Sheth, 1973). Buyers instead look for maximum price advantages and costs savings (Sheth, 1973; Mast and Hawes, 1986; Dadzie et al., 1999; Albert, 2003; Harrington and Tjan, 2008; Töllner et al., 2011).

However, a closer and more critical look at the empirical work on organizational purchasing to date reveals that current understanding of industrial end users' influence in industrial buying processes is still limited. On one side, studies often include in the users' category organizational actors who are actually decision makers, (e.g., engineers, chief operation officers, and shop foremen) and not those who physically handle the product once purchased (Howard and Doyle, 2006). On the other, research tends to focus on products implying a low degree of product-user interaction. Examples include operating supplies, raw materials, minor equipment, and even services (Appendix A). Put differently, research has generally focused on products and product purchasing in which end users are supposed to experience a low level of purchasing task involvement. According to Gilliland and Johnston (1997), end users have a high level of purchasing task involvement, which is not necessarily linked to product performances and a product's technical features. Drawing on Celsi and Olson (1988), they suggest that purchasing task involvement is guided by four drivers: "existing personal relevance," "personal goals and values," "ego-related significance of the object," and "personal consequences of the purchasing decision."

Existing personal relevance is the feeling an individual has for the product based on previous interactions with the object. As such, end users are claimed to be the category of buying center members for whom feelings of personal relevance are most significant (Gilliland and Johnston, 
1997). Personal goals and values refer to the linkage between an individual's needs, goals, and values, and a specific product's attributes and benefits (Celsi and Olson, 1988). Ego-related significance of the object refers to the perceived linkage between a specific product and a buying center member's self-esteem. Products that have a high ego-related significance manifest in the attempt of buying center members to purchase certain products that would bolster their self-esteem and to experience higher levels of purchasing task involvement (Pedeliento et al. 2016). Finally, the personal consequences of the purchasing decision refer to feelings of personal relevance toward the product being purchased due to positive/negative effects determined by the outcome of that specific purchasing decision. However, it is worth noting that a higher level of purchasing task involvement does not necessarily lead to a higher level of influence. Involvement is a feeling of personal relevance (Gilland and Johnston, 1997) and, as such, does not refer to manifest influence, which instead expresses the extent to which an individual is able to affect the course of action and the decision outcome of the buying process (McQuiston, 1989). Such individual ability to affect the course of action is generally considered to be contingent upon resources of power individuals can leverage in interaction with others in specific contexts by pursuing specific influence strategies (French and Raven, 1959; Giddens, 1984; Yuk1, 2002).

\section{Power and influence strategies in organizational buying}

Previous scholars have warned about the need to link individuals' influences in buying centers with the power that they can deploy (Nicosia and Wind, 1977; Johnston and Bonoma, 1981; Jackson et al., 1984; Berkowitz, 1986; McQuiston, 1989; Kohli, 1989). While early investigations justified individuals' ability to influence organizational purchasing by the hierarchical position they hold, scholars soon recognized that influence depends on power, i.e. the individual capacity to influence people and events (Kohli, 1989; Ronchetto et al., 1989; Kohli and Zaltman, 1988; Farrell and Schroder, 1999).

Accordingly, the enactment of power presumes the control over "resources" or "bases" of power, that, if mobilized, can change the relations of autonomy and dependence among actors or collectivities within the context in which social interaction occurs (Giddens, 1984). Five bases of power are generally considered (French and Raven, 1959): reinforcement, referent, legitimate, expert, and information power. Accordingly, an actor can push others to comply with her requests by leveraging different sources. Because the person is in a position to mete out rewards or punishments (reinforcement power). Because others have regard and esteem for 
him/her (referent power). Because s/he holds a particular formal rank within the organization (legitimate power). Because $\mathrm{s} / \mathrm{he}$ is knowledgeable about relevant issues at stake (expert power). Because s/he has access to and control over relevant information that others cannot access (information power) (French and Raven, 1959). In line with Kohli (1989), expert power is the most important determinant of manifest influence, followed by reinforcement power. Expert power is related to manifest influence especially in buying centers in which cooperation among members prevails over hostility, and in buying situations that do not require quick decisions and that are not accompanied by strong influence attempts by one of the members. In contrast, reinforcement power relates more significantly to manifest influence when accompanied by strong influence attempts and in buying centers that are small, not very collaborative, and under time pressure. Other bases of power, in contrast, have little role in manifest influence.

Farrell and Schroder (1999) investigated how individuals enact these bases of power to materially exercise influence. Drawing on Frazier and Summers (1984), they identified six influence strategies: request, information exchange, recommendation, promise, threat, and legalistic pleas strategies. Requests strategies are those in which the source of power merely informs the target of the actions s/he would like the target to take, without directly implying any specific consequence for the target due to compliance or noncompliance. Requests strategies are thus linked with referent power. Recommendation strategies consist in suggestions made by a source of power that following a specific course of action is likely to be beneficial. Recommendation strategies are thus linked with expert power. Promise/threat strategies consist is the source's pledges to provide the target with a specific reward/punishment contingent on the target's compliance/noncompliance with the source's stated desires. Accordingly, promise and threat strategies are the enactment of reinforcement power. Information exchange strategies are enacted in the form of consultation without suggesting specific target actions. However, as information is a critical resource, and is often shared in exchange for other benefits, information exchange strategies can overlap with promise and threat strategies, implying a certain degree of reinforcement power (Farrell and Schroder, 1999). Finally, legalistic pleas strategies are deployed when the source relies on a formal agreement or on formal organizational that either require or suggest the target performing a certain action. These strategies are linked with the corresponding bases of power known as legitimate power. 
Yet, although these works are notable for underlining power as an antecedent condition of manifest influence, they have three significant limitations.

First, they do not reveal either the buying center's member(s) who possesses such power or the center's member(s) toward which the specific influence strategy is deployed. Second, informants are selected from different purchase situations, ignoring the context of the industry and the specific buying situation, i.e. they do not consider that influence strategies may vary depending on the type of product being purchased. Last, they do not consider the role of end users as "powerful" actors or as targets of influence strategies.

Given these gaps, we provide a study by focusing on a buying situation in which end users' purchasing task involvement is supposed to be high due to the significant degree of interaction through usage between the product and the end user. Acknowledging that purchasing task involvement is not necessarily related to manifest influence (Gilliland and Johnston, 1997; Shamdasani et al., 2001), and that influence is manifested through the enactment of power (French \& Raven, 1959; Kohli, 1989; Yukl, 2002), we give particular attention to the ways in which influence attempts are materially performed (Venkatesh et al., 1995; Farrell \& Schroder, 1999).

\section{Methodology}

Heavy trucks' purchasing was chosen as a suitable research setting for investigation. Being capital equipments, trucks purchasing would suggest a high level of collegiality in purchasing decisions. However, the fact that they are purchased on fixed terms (av. once every 5-6 years), truck purchasing can be framed as modified rebuy, a situation in which the level of users' involvement in the buying process is considered to be low (Robinson et al., 1967). Nonetheless, because trucks are used by end users on a daily basis they configure a case of buying task in which end users' involvement is supposed to be high (Gilliland and Johnston, 1997). Recent studies conducted on trucks and truck drivers have in fact shown that it is rather common that users develop feelings of attachment toward the truck (Pedeliento et al., 2016). New truck purchasing renders thus a case in which despite the very nature of the buying situation would suggest a low level of users' influence, their level of purchasing task involvement should instead drive them to deploy purposeful attempts to play influence over the purchasing process regardless of formal status within the firm's hierarchy (Ronchetto et al., 1989).

We opted for a qualitative approach through one-to-one interviews (Strauss and Corbin, 1990; Arksey and Knight, 1999) and preferred it to a quantitative one to avoid limiting the 
understanding of the phenomenon here studied to a restricted number of attributes and variables (Howard and Doyle, 2006; Lewin and Donthu, 2005). The interviewers had extensive prior experience of the industry and could rely on established contacts with key industry players, who provided help to gain access to informants. The research was carried out in Italy.

Overall, 90 key-informant interviews were conducted with trucks' end users, buyers and sellers. Focusing on multiple categories of informants is considered suitable to enrich the understanding of organizational purchasing behavior (Kumar et al., 1993; Ronchetto et al., 1989) and to limit self-reported biases, which may not be congruent with reality, making research results questionable and unreliable (Silk and Kalwani, 1982; Crow and Lindquist, 1985; Kohli and Zaltman, 1988). In particular, besides buyers and users, we also decided involving truck sellers since, having adequate knowledge of purchasing (Keszey and Biemans, 2017) they were judged to be appropriate for both deepen the understanding of the phenomenon here studied and to cross-check findings gathered from other key informants. Since salespeople have frequent interaction with buyers and other organizational actors that take part to organizational purchasing, they are in a unique position to serve as a primary source of information (Gordon et al., 1997)

On the suppliers' side, we interviewed 42 sales persons equally divided by brands. Specifically, we collected six interviews for each of the brands selling heavy trucks in the European market: Daf, Iveco, Man, Mercedes-Benz, Renault Trucks, Scania, and Volvo Trucks. Sales persons were chosen randomly from a list of possible contacts we had access to, by controlling only for their level of seniority within the industry (at least five years of experience in the role).

On the buyers' side, we gathered data from 24 informants working for trucking companiesthat is, companies that haul goods on behalf of customers-who declared they were responsible for purchasing of trucks (company owners and purchasing personnel). Trucking companies involved in the study were chosen on the basis of the number of trucks composing the freight, a variable that is often used to categorize trucking companies by dimensional class. We selected informants on the basis of organizational dimension, as size is a relevant contingency determining the dynamic of power enacted by buying centers' members (Kohli, 1989; Venkatesh et al., 1995). Companies and informants were divided into four classes: up to 3 trucks (micro-firms); from 4 to 10 trucks (small firms); from 11 to 50 trucks (medium firms); and more than 50 trucks (large firms). Although 50 trucks can be considered a low threshold to consider a firm a big one, it is worth noting that according to the National Association of Trucking Companies, micro and small firms account for about 90 per cent of the number of 
Italian trucking companies. Trucking companies were chosen regardless of the brand(s) owned by composing a group of informants as much diversified as possible in terms of brands owned. Six interviews for each of the mentioned dimensional classes were collected. Finally, end users were selected on the basis of the same dimensional criteria by also controlling for the brand driven. Specifically we interviewed six drivers for each of the aforementioned class. As for the sellers, end users were selected on the basis of their expertise in the trucking business (minimum ten years of experience as drivers) to avoid the risk of interviewing informants that do not have sufficient knowledge of truck purchasing. Appendix B contains detailed information of buyers and end users involved in the study. Information on sales person are not provided as the only criteria we used was ensuring equal coverage of informants for each brand. Interviews were conducted in between 2012 and 2016. The data totaled about 300 pages of field notes and interview transcripts.

The interviews for each of the three groups of informants relied on a similar canvass and did not follow a rigid grid. The role of the interviewer was to favor the emergence of topics dealing with end users' influence in truck purchasing instead of explicitly asking causal effects or patterns of influence. We thus explicitly avoided mentioning or focusing on power dynamics within the buying center, and used informants' accounts as the basis to infer patterns of power and influence strategies in an inductive way (see Miles and Huberman, 1984; Granot et al., 2012). This choice was taken to avoid asking questions that implicitly presume the existence of power, influence strategies, and outcomes of such strategies (and the relationships among them), to minimize the biases that are likely to emerge when power and influences are investigated as self-reported reports of informants (Silk and Kalwani, 1982; Crow and Lindquist, 1985; Kohli and Zaltman, 1988). We asked informants to give extensive details of new trucks' purchasing experiences, and gradually drove the discussion to gain reflexive accounts about whether, how and to what extents end users were involved in the purchasing decision. Informants' accounts were then interpreted in an emic fashion. Accordingly, the interpretation relies on the respondent's own terms and category systems rather than the researcher's, and do not incorporate neither inferences beyond the evidence provided by the transcript, nor quantifying methods (Thompson et al., 1989). Once collected, interview transcripts and field notes were paralleled to the literature to allow the emergence of relevant themes to illuminate our understanding of end users' influence in organizational buying. 


\section{Findings}

\subsection{Users have high levels of purchasing task involvement}

Purchasing task involvement is found to be a common feeling among truck drivers, and largely determined by personal sources of relevance of the product. Similar to previous studies we found that buyers look for maximum price advantages and costs savings. Nevertheless, differently, in the context investigated we found that users' purchasing task involvement is only marginally related to technical features of the offering, to its performances, or to its deployment (Sheth, 1973; Pingry, 1974; Mast and Hawes, 1986; Martin et al., 1988; Dadzie et al., 1999; Albert, 2003; Harrington and Tjan, 2008; Töllner et al., 2011). Rather, it is largely motivated by end users' interest in other non-utilitarian and self-representational product features mostly dealing its aesthetic appearance, and to the prestige and image of the brand. When asked about the reasons that prompt end users to affect the purchasing process, an entrepreneur of a small company said,

I have always to struggle with my employees when I buy a new truck. They do not understand that trucks for me are working tools. Me, too, I like lights, colors, leather seats, premium cabs, but I have to worry about the bills at first, and I cannot afford their requests. [Quote 1]

A Man sales person affirmed,

Drivers and entrepreneurs have completely different stakes: drivers are interested in the brand prestige, to the truck's physical appearance, to the accessories package, to the engine power, etc. All things that allow them to feel better drivers or to appear as such in the eyes of their colleagues. Entrepreneurs instead look at the price, fuel consumption, efficiency and post-sales services. [Quote 2]

A driver employed in a truck fleet with eight trucks affirmed:

You now, you must love your truck. You have to feel good when you drive your truck. It is a second house. Actually, I consider my truck as my first house as I spend more time on the truck than at home. If you have a truck that you like, that you feel proud of, you work better ... you feel proud of it. Wherever you go, they watch at you. You feel more self-esteemed. [Quote 3]

From the quotes above, it is evident that end users are highly involved in the purchasing of a new truck because of a high ego-related significance of the object, i.e. the perceived linkage between a specific product and a buying center member's self-esteem. Buying the 'right' truck is thus considered a way to show off the professional status of the driver, as a social proof of the drivers' professionalism toward others.

However, while the existence of a different set of criteria emerged also when we interviewed drivers, they frame their requests and stakes into a completely different light. They contend against decision makers that their requests are often misinterpreted by buyers. The following quote is exemplary of this discrepancy. 
In my company, drivers cannot say anything before purchasing of a new truck. They [the decision makers, ndr.] look at price and don't consider the driver in the choice. They believe that a possible request of mine of having a more powerful engine for example, is a whim and not a necessity. They believe that buying a less powerful and thus less expensive - truck allows the company to save money. But they are wrong. If I don't have enough horse powers, I have to step on the gas resulting in higher consumptions. The problem is that many of my colleagues - if asked about their preferences - would ask an $800 \mathrm{HP}$ vehicle even if for the job they do they don't need it. Thus, owners buy the same truck for every driver and no one is happy. [Quote 4]

The lack of end users' involvement in the purchasing of a new truck makes drivers somehow frustrated or not sufficiently gratified for their work.

When they give you a new truck you feel proud of yourself, you feel satisfied for what you do and for what you have done because a new truck is a prize to your professionalism and to your capabilities. Many bosses do not understand this issue. They do not understand the importance we attribute to a truck. For them the important thing is that you make the wheel rolling ... hence when they give you a new truck is like ... is always a bittersweet event. Of course you are happy because you feel somehow rewarded for your work, but it is at the same time frustrating as no one asks you if you prefer the truck to be white or red, with manual or automatic gear, etc. [Quote 5]

There are however several cases in which the buyer leverages on his/her knowledge or expertize about the technical characteristics that a truck needs to have to keep control over the whole purchasing process. Truck buyers (especially company owners) are very often users themselves, or used to be drivers before becoming entrepreneurs. As the owner of a medium company declared,

I have gasoline flowing in my veins. I've been in the trucking industry since 1972. I drove regularly for 30 years, and I know perfectly everything needs to be known about trucks and transportation in general. The driver cannot say anything, as I know better than them the truck technical details, its functioning, and if it fits with the business we do. [Quote 6]

\section{The CEO of a large company that owns more than 400 trucks affirmed,}

When we started the business the company had only two drivers. Me and my brother. Now we have 451 truck drivers employed, and each of them has his/her truck to drive. Once they are assigned a truck, they are the only one that can drive it. However, they do not have any possibility to influence the purchasing, neither concerning the specific truck, nor regarding the brand. I used to be a driver, and when possible I still enjoy driving. So, I have the expertise needed to purchase the right products without needing to involve the drivers. Of course, the drivers are not happy of this. When the company was smaller, at the beginning of the 90 s when there were about 10 drivers employed, we used to involve the drivers in the purchasing choice taking into account also their requests. [Quote 7]

\subsection{Users influence is contingent on firm's size and core business}

When asked about under which conditions end users can take part to the purchasing decision of a new truck, all of the 90 informants interviewed declared that firms' size is a main determinant. According to our findings it is especially in small companies that drivers' can play an influence while in big firms end users are marginally influent.

As declared by the owner of a fleet with about 100 trucks, 
In small companies, the driver is the boss. In our company, all the drivers are the same (...) I decide what to buy, and I will never let the driver even think to come to me and ask for a truck red or yellow, or asking for particular accessories, or even trying to influence the brand choice. No way. [Quote 8]

The owner of a small company with a truck fleet of four trucks on the contrary affirmed,

My company is a small one. I have to take into account my drivers' needs. I cannot simply say, this is the truck, and I don't care about you and your needs. It is normal that I consider their opinion when I have to buy a new vehicle. Small companies you know are like families. You should care about the members of your family and try to make them happy if possible. (...) In big companies instead the relationship between the boss and the driver is depersonalized, and there's no way for the driver to be influential in the truck's choice. [Quote 9]

These quotes show a different dynamic compared to what emerged in previous studies. While scholars suggest that in small companies purchasing decisions tend to be taken by the company owner in an autocratic fashion (Spekman and Stern, 1979; Bellizzi, 1981; Ellegaard, 2006, 2009; Delécolle, 2011), our data suggest that is especially in small companies that end users are active participants in the buying process or at least are in the position to be influential. Opposite evidences are found in large companies where we found that the purchasing process tends to be entirely held by the company owner or by the organizational agent deputed to the company's purchasing.

In addition to firm size, an additional contingency affects the possibility of the end user influencing the purchasing process: the type of business of the company the driver works for. In particular, two different types of business customers are identified: those that have transportation as their main core business (transportation companies), and those that have a different core business (for example, manufacturing or retail) and need trucks to deliver their goods to channel members or to final customers. A driver working for a steel manufacturing company said,

I work for a company that produces steel made products and that has an internal freight division to deliver its products to clients. We [the drivers] have free reign over the choice of the truck. Now I am driving a quite old vehicle but we are planning to replace it very soon. If my boss does not involve me in the choice of the truck, I will get pissed off as I am the driver, the one that stays all day long on the truck and the one that knows what a truck is and should be. [Quote 10]

\subsection{Buyers opportunistically leverage users' buy task involvement}

The existence of a high level of purchasing task involvement of end users is reinforced by the evidence that several informants affirmed that, users' are often allowed taking part to the purchasing process as a form of personal reward or company benefit. Hearing the voice of the driver is a way to keep them happy and satisfied with their jobs as well as to reward them, their professionalism, and their loyalty to the company.

On the suppliers' side, a DAF salesperson declared, 
I have had experiences with companies in which the driver was involved because the boss wanted to reward him. In most of the cases, the most beautiful truck of the fleet is not driven by the company owner (if he is a driver himself) but by the driver he considers as the best or the most trustworthy. I saw drivers saying, "No, I would never drive that truck," and the entrepreneur bending his back. [Quote 11]

\section{A Volvo salesperson recounts,}

Nowadays finding a reliable driver is very difficult. When choosing a truck, some employers give their employees free reign to retain them as long as possible (...). It happens that a business owner that needs a new truck says,: On this new truck I want leather interiors or the air conditioning on the roof, or other luxury accessories that in normal conditions the buyer would never buy, to reward the driver because he is loyal or because he is an outstanding employee. [Quote 12]

The professional quality achieved by drivers, as well as their organizational relevance, seem to be somehow connected with the participation of users in new trucks purchasing. In some cases, in addition, buyers leverage drivers' participation in truck purchase decisions as a way to obtain something in exchange. As a Man seller said,

In some cases the company's owner involves drivers in the buying decision with the precise objective of having something in exchange. The unwritten rule is, I will buy you the truck you want and, in exchange, you don't bother me when you have to work two hours more. [Quote 13]

The owner of a company with three trucks echoes this voice:

You know, I please him [the driver] with something he desires so that if he has to work a couple of hours more he doesn't bother me. I have to please my employees, because it is getting harder and harder to find good drivers. [Quote 14]

Interestingly, users are conscious that many companies' owners opportunistically leverage their involvement in truck's purchasing. A driver declared in fact,

I used to be very interested in trucks when I was young. At that time, I was willing to let myself down with my boss to obtain the truck I desired or to have some specific accessorizes. You know, it is an exchange, I bought the truck you like, so don't ask for extra paying or don't bother me if you have to work more or if I am a week late with the salary. Now I have a family so the salary is first and the truck is of secondary importance. Of course, I would love to drive a truck nicer than the one I currently drive. But if I have to worsen my work condition for that ... I am not that kind of driver anymore. [Quote 15]

According to our informants, drivers are even willing to diminish their personal welfare as long as they can see their brand related wants and desires satisfied. A Scania sales person declared, We have some clients that use our brand to attract employees. We can say that very often drivers are willing to gain less money to drive the brand they want. Drivers are in love with trucks; they use it every day and develop a love for their truck and for a specific brand. Luckily, our brand is one of the most beloved. [Quote 16]

On the other side, users' feelings of involvement seem to be amplified by the undesirability of certain brands. When end users feel that the choice of a specific brand can bring negative effects for them, this is reflected on their level of purchasing task involvement and on their attempts to lobby the decision maker (when this is possible). Interview transcripts reveal that the rate of 
involvement sought by users is especially due to the self-representational value that some brands have for them. On this matter, for example a driver said,

Well, I can accept that they don't hear my needs before a new truck purchasing, but they cannot oblige me to drive a truck I hate. When they purchased some new [brand omitted] I immediately said no. I don't want to drive that truck. If you force me to drive that truck tell me now clearly and I will look for a job in another company. I don't want to work on a truck I dislike. [Quote 17]

These evidences are in line with the results drawn by Yamamoto and Lambert (1994), who found that product appearance have a positive influence (although marginal) on individuals' preference also in industrial contexts, especially for its end users. But they are different in showing that - in this context - besides affecting product appearance is also a main determinant of users' level of purchasing task involvement implied in the purchasing process. Results also provide additional confirmation of those recently found by Pedeliento et al. (2016), who have shown that truck owner-operators' buying decisions are more affected by emotional feelings toward, and identity-related features of trucks and truck brands, rather than by their technical and performance characteristics.

\subsection{Users' influence in brand choice and in product configuration}

As the role that brands play emerged spontaneously throughout the course of interviews, we asked follow up questions on this matter to understand whether end users' influence could extend to brand selection. The view of buyers, sellers and drivers were found to be different; none of the entrepreneurs or other informants responsible for heading the purchasing of trucks interviewed claimed (or admitted) to take into account drivers when choosing a brand regardless of firms' size. The vendors instead, while affirming that the choice of the brand is generally made by the company owner, offered many instances in which the driver was influential. The drivers, on their side, clearly stated that they can be influential also in brand selection although their influence varies according to company's size and to their interest for a specific brand. For example, when the driver is a brand enthusiast it is likely that s/he will do his/her best to influence the buyers' choice although such influence is seldom successful. A Mercedes-Benz salesman affirmed,

I have a customer company where all the drivers are in love with Mercedes, and they help me quite a lot to convince the boss to do not switch to other brands. You know, Mercedes is more expensive than other brands (...). The boss knows that switching the brand would have been interpreted by the employees as a prank toward them. He tried, but the drivers rebelled (...).I think that it is not a chance that drivers working for that company average around 10-15 years service with it. [Quote 18] 
However, while the influence that drivers can play in brand selection is rare, end users were found to be influential especially with respect to the choice and the purchase of accessories, equipment, and other technical details of the truck. A driver working in a small company said,

There is a sort of unwritten rule: the boss decides the brand and gives some rooms to the driver that can choose some extra accessorizes and variation of the equipments. There is huge difference in price from a brand to another and we cannot ask our boss to spend up to 20 or 30,000 euro more to buy the brand we like. He is the owner, we cannot force him to spend more than that he can actually afford. [Quote 19]

\section{Unravelling bases of power and influence strategies}

Findings drawn suggest that purchasing task involvement is tightly connected to users' influence attempts and with their willingness to participate in buying decision. They also reveal that users' purchasing task involvement can be either resisted or strategically leveraged by buyers. As buyers recognize that users have a high feeling of relevance in the purchasing decision, they are found to opportunistically decide whether or not users can manifest influence, depending on the positive effects that such participation can bring for them or for the company.

Understanding whether purchasing task involvement relates to manifest influence requires understanding the bases of power mobilized and the influence strategies deployed by individual actors in relation with others (Kohli, 1989; Venkatesh et al., 1995; Farrell and Shroder, 1999). The analysis of the interviews conducted allowed us to inductively identify both the bases of power mobilized by end users toward buyers, and the influence strategies they deploy; and, on the other side, to shed light on the bases of power mobilized by buyers toward end users and the influence strategies they deploy. It is worth remembering on this matter that to minimize self-reported biases (Silk and Kalwani, 1982; Crow and Lindquist, 1985; Kohli and Zaltman, 1988) we purposefully avoided asking questions that implicitly presume the existence of power, influence strategies, and outcomes of such strategies.

Differently from previous studies (Doyle et al., 1979; Moriarty and Spekman, 1984; Howard and Doyle, 2006; Moon and Tikoo, 2002), our findings suggest that influence strategies deployed by end users seldom derive from their expertise. None of the buyers and none of the sellers we interviewed stated that drivers rely on their expertise to manifest influence. The only exception we found were companies that do not have their core business in transportation but need to buy trucks to deliver the products they make [see Quote 10]. Thus, expert power and recommendations strategies are deployed by end users to compensate the lack of expertise of the buyers. On the other side, several drivers claimed that their expertise as product users' 
should be more significantly taken into account by decision makers, than they actually do. What emerges from the interviews is that cases in which drivers leverage on their expertise to be influential are not rare, although their requests can be frequently misinterpreted by buyers and seen as motivated by reasons other than obtaining better or more performing products [see Quote 4]. The marginal use of expert power by end users we unveil in this context make it legitimate to suspect that new trucks' purchasing is somehow related to some degrees of conflicts between buyers and users since expert power and recommendation strategies are especially salient in buying centers in which cooperation among members prevails over hostility. Our findings offer thus a case that is diametrically different from Kohli (1989) and Venkatesh et al. (1995), where expert power and recommendation strategies were found to be predominant.

Users were found as sources of reinforcement power and to pursue promise and threats strategies to make their voices heard [see Quote 11, 13, 14]. This form of power that drivers hold however seem to not stem from formal norms, nor from their formal status, such as their position within the company's hierarchy (Ronchetto et al., 1989). Rather, from informal norms that regulate the relationship between the buyer and the user. For example, we found some senior truck drivers that deploy reinforcement power leveraging negative consequences (e.g., leaving the company) or positive consequences (e.g., accepting a higher workload for the same salary), in case of their eventual lack of or involvement in the purchasing process [see Quote 17]. Referent power is also salient in the context investigated here. Findings show that in some instances users deploy request strategies explicitly informing the buyer about what he/she expects from the purchasing of a new truck without directly implying any specific consequence due to compliance or noncompliance [see Quote 18]. Referent strategies could be also linked to the informal position the end users hold within the company, such as seniority, trustworthiness, or loyalty [see Quote 12]. The other two forms of power (legitimate and information power) and the corresponding influence strategies did not emerge as salient to the findings.

It is worth noting that according to our informants influence strategies deployed by users can regard either the definition of product specifications, the choice of brand, or both. Thus, differently from previous studies, we found users affecting also the brand choice (although seldom) and not only the definition of the product's characteristics (Berkowitz, 1986; Tanner, 1998) (which is more common also in the context here studied). 
On the buyer side, the interviews collected reveal that buyers rely on legitimate power and deploy legalistic pleas strategies to avoid making the users' requests negotiable [see Quote 6]. Although we found buyers' legitimate power to be deployed in both small and large firms, our findings suggest that buyers are keener to mobilize this base of power especially in large companies where the hierarchical distance between buyer and user is perhaps a sufficient condition to prevent the latter trying to influence the former [see Quote 8, 9].

In some cases in contrast, reinforcement power and corresponding promise and threats strategies are brought into action to push the driver into not trying to affect the purchasing decision, or, in turn, to let the driver be influential. The buyer's power to decide whether or not drivers' requests can be taken into account was found in this context to be also dependent on the buyer's ability to motivate users to put effort into their jobs beyond what is generally required (e.g., by accepting a higher workload for the same salary) [see Quotes 11-15]. Differently stated, buyers often leverage users' purchasing task involvement for their own personal interest and profit.

Expert power also emerged as a base of power often exploited by organizational buyers toward end users, especially in those companies in which the buyer has product experience [see Quotes $6,7]$. It is, however, interesting to note that expert power to some extent overlaps with legitimate power and with referent power as it is coercively brought into being without regard for whether users actually consider the buyer knowledgeable enough. The buyer considers him/herself a trucks expert and, as such, to be in the position to impose a specific buying choice as the right one. The buyer's felt expertise is thus reinforced by his/her legitimate organizational role. This extends what is suggested by Frazier and Summers (1984) and by Venkatesh et al. (1995), who note that as recommendation strategies explicitly express the individual's preferences or needs, they implicitly entail a certain level of coercion. Our findings show that as expert power is "reinforced" by legitimate power, it is coercively applied without needing any explicit recommendation to be effective.

Finally, although we found that users are in some cases in the position to affect the brand choice, it is worth noting that this information was gathered only from the vendors and from the drivers, while none of the buyers declared (or better admitted) that end users could manifest influence in the brand's choice [see Quote 19]. This makes it legitimate to suspect that buyers see this occurrence as detrimental to the legitimate power they hold in force of the formal organizational hierarchy. And it also makes legitimate to hypothesize that threat and promise strategies enacted by users may be exploited when the buyer cannot fully rely on the sources 
of power he/she holds to materially impede users' manifest influence. Targets of power (e.g., users), tend to align to the requests of a source of power (e.g., the buyer) only if they acknowledge that he/she materially holds this power. Alternatively, they might not see the influence strategy deployed and the possible consequences stemming from noncompliance as credible, and subsequently try to seize an advantage for themselves. For example, it was visible from the interviews collected that there are cases of companies in which the buyer tried to leverage power to switch to a different supplying brand, but users resisted this choice, even forming a coalition of power (Ronchetto et al., 1989) [see Quote 18].

\section{Conclusions}

This research contributes to research on end users' influence in organizational buying processes by bridging two gaps. One relates to benefits users seek to satisfy taking part in organizational buying processes. We challenged the established view that users look for products that improve their work performances, and draw on the concept of purchasing task involvement (Gilliland and Johnston, 1997) to achieve a deeper understanding of users' influence in organizational buying. However, as purchasing task involvement is an individual feeling of relevance, it does not necessarily drive to manifest influence. This led us to identify a second gap that relates to the nature of power held by end users and to the influence strategies they deploy.

Three main findings can be underlined. First, we found that when users have a high level of purchasing task involvement they try to lobby the buying decision regardless of the power they have or they can deploy. Second, we provided empirical support for the assumption that users' purchasing task involvement is primarily determined by personal sources of relevance toward the product (Gilliland and Johnston, 1997), and secondarily by the product's performance or technical features. Third, we found that purchasing task involvement leads to manifest influence under specific distributions of power between the buyer and the user, and under specific contingencies.

We draw on previous studies on power and influence strategies (French and Raven, 1959; Kohli, 1989; Venkatesh et al., 1995; Farrell and Schroder, 1999) to make sense of the dynamic and relationship of power behind users' influence. We show that users can be influential beyond their expertize and rely also on reinforcement and referent power under specific informal norms that regulate the relationship between the buyer and the user such as users' seniority in or loyalty to the firm. Expert power on the contrary is generally irrelevant except for companies that do not have hauling as their core business. Buyers, in turn, rely on legitimate 
or expert power to preventing users from influencing the buying decisions, and/or on reinforcement power when they are keen to allow users to participate.

In addition to partly filling these gaps, this research brings an additional contribution to the specific stream of research on power in organizational buying relating to the methodology applied. Differently from previous studies (Kohli, 1989; Venkatesh et al., 1995; Farrell and Schroder, 1999), we adopted a qualitative rather than a quantitative method. Using in depthinterviews we were able to gain deeper insights concerning users' influence in buying processes. Although quantitative methods allow collecting a great amount of pre-specified data from a significant number of respondents, they limit understanding to a finite number of variables. As Howard and Doyle (1998) have claimed, research on organizational purchasing should be conducted by using qualitative methods, as they allow achieving a better and more complete understanding of the multiple forces affecting organizational buying. In addition, we were able to show that sources and influence strategies can overlap and are not necessarily at play one at a time. Prior quantitative research on power relationships in organizational buying tends to consider the type of power mobilized and the corresponding influence strategy deployed as being more important than others when they are correlated with manifest influence. Qualitative enquiries instead can more deeply grasp the multiple sources of power and corresponding influence strategies that are enacted simultaneously to determine manifest influence. In addition, we also believe that this research contributes to research on organizational buying for the inclusion of sales people as key informants. They were important not only to cross-check findings gathered from other key informants, but especially to let some topics emerge that did not emerge spontaneously from interviews to buyers and users.

\subsection{Managerial implications}

The results allow formulating several managerial implications addressed to both sellers and buyers. For the sellers, a greater involvement of end users is suggested as a possible way to achieve a better competitive positioning, especially in markets characterized by the prevalence of micro-small over big trucking companies. Commercial and communication strategies should hence be designed to appeal to both buyers and users, balancing task and non-task product related features such as aesthetic. For example, leveraging products' appearance can be an important source of competitive advantage vis-à-vis competitors especially when the structural characteristics of the demand favor greater involvement of users in purchasing decisions. Gemser and Leenders (2001) suggest that when product technology begins to level out, product 
aesthetics can be a great source of differentiation and competitive advantage. In the truck industry in particular, leveraging the aesthetic content of the product can be a valuable path to achieving better positioning, since product quality and performance among brands is increasingly leveled.

The importance that the aesthetic content of the offering plays in raising users' purchasing task involvement deals not only with marketing efforts, but also with product development decisions and with the configuration of the product. Some successful players, for example, owe part of their success to the adoption of modularization of their products allowing higher personalization (Persson and Åhlström, 2006).

Concerning the demand side, allowing drivers to participate in the purchasing process and giving them the chance to influence decisions can be an effective leverage to increase their job satisfaction and to keep them loyal. Previous studies focused on occupational issues in the trucking industry (Taylor, 1994; Min and Emam 2003) found that trucking companies are increasingly struggling with difficulties in retaining qualified drivers. The 2014 report of the American Transportation Research Institute (Torrey and Murrey, 2014) denounces a severe shortage of qualified drivers (ca. 25,000 over actual supply) that continues to affect the industry. In such a scenario, it is important for companies to retain qualified drivers and to keep them loyal to maintain both the continuance and the quality of their business.

Even though they found some organizational variables predicting drivers' loyalty, they did not take into account the truck as an incentive to keep drivers loyal in the long run.

\subsection{Limitations and future research}

The results and the managerial implications should be viewed in light of the constraints of the study. First of all the product category investigated can be considered a unique case in the heterogeneous landscape of business products. Similar investigations of other industrial products will probably unveil a lower level of users' purchasing task involvement and a lesser significance of personal sources of relevance. Similar studies are also needed on products that are used for both work and private purposes. Personal computers or tablets for example that are used on a daily basis both at home and at work offer a valuable research setting to understand whether feelings of personal relevance and corresponding purchasing task involvement diverge or converge depending on the motives for which they are used. Other factors that can affect users' purchasing task involvement-beyond product usage — should also be investigated. For example, how does business product advertising affect users' feelings 
of relevance? How does users' participation in brand initiatives—such as brand fests-affect purchasing task involvement and users' influence attempts? The second limitation concerns other sources of power affecting users' participation in organizational buying outside of the dyadic user-buyer relationship. An interesting line of inquiry can be to investigate the power held and the influence strategies deployed by sales representatives to push the buyer or the user to affect the outcomes of the decision process in his/her favor. In general, more research is needed to shed light on influence strategies deployed by agents other than those belonging to the buying center.

Finally, the finding that allowing drivers to manifest influence in the purchasing process of trucks can lead to higher levels of loyalty and a lower turnover rate deserves to be deepened by means of specific studies.

\section{References}

Albert, T. C. (2003), "Need-based segmentation and customized communication strategies in a complex-commodity industry: A supply chain study", Industrial Marketing Management, Vo. 32 No. 4, pp. 281-290.

Arksey, H. and Knight, P. (1999), Interviewing for Social Scientists, Sage Publications, London.

Bellizzi, J. A. (1979), "Product type and the relative influence of buyers in commercial construction", Industrial Marketing Management, Vol. 8 No. 3, pp. 213-220.

Bellizzi, J. A. (1981), “Organizational size and buying influences”, Industrial Marketing Management, Vol. 10 No. 1, pp. 17-21.

Berkowitz, M. (1986), "New product adoption by the buying organization: Who are the real influencers?", Industrial Marketing Management, Vol. 15 No. 1, pp. 33-43.

Bonoma, T.V. (1982), "Major Sales: Who Really Does the Buying?", Harvard Business Review, Vol. 60 No. 3, pp. 111-119.

Celsi, R. L. and Olson, J. C. (1988), "The role of involvement in attention and comprehension processes", Journal of Consumer Research, Vol. 15 No. 2, pp. 210-224.

Celuch, K., Goodwin, S. and Taylor, S. A. (2007), "Understanding small scale industrial user internet purchase and information management intentions: A test of two attitude models", Industrial Marketing Management, Vol. 36 No. 1, pp. 109-120.

Chandler, J.D. and Johnston W. (2012), “The organizational buying center as a framework for emergent topics in business-to-business marketing”, in Glynn M. S. and Woodside, A. G. 
(Eds.), Business-to-business marketing strategies, cases and solutions, Vol. 18 Advances in Business Marketing and Purchasing, Emerald Groups Publishing, Bingley, pp pp. 41-87.

Crow, L. E. and Lindquist, J. D. (1985), "Impact of organizational and buyer characteristics on the buying center", Industrial Marketing Management, Vol. 14 No. 1, pp. 49-58.

Dadzie, K. Q., Johnston, W. J., Dadzie, E. W. and Yoo, B. (1999), "Influence in the organizational buying center and logistics automation technology adoption", Journal of Business and Industrial Marketing, Vol. 14, No. 5/6, pp. 433-444.

Delécolle, T. (2011), "Very small enterprises as professional customers: A qualitative study", International Business Research, Vol. 4 No. 2, pp. 20-30.

Doyle, P., Woodside, A. G. and Michell, P. (1979), "Organizations buying in new task and rebuy situations”, Industrial Marketing Management, Vol. 8 No. 1, pp. 7-11.

Ellegaard, C. (2006), "Small company purchasing: A research agenda", Journal of Purchasing and Supply Management, Vol. 12 No. 5, pp. 272-283.

Ellegaard, C. (2009), "The purchasing orientation of small company owners", Journal of Business and Industrial Marketing, Vol. 24 No. 3/4, pp. 291-300.

Erevelles, S. (1998), “The role of affect in marketing”, Journal of Business Research, Vol. 42 No. 3, pp. 199-215.

Farrell, M. and Schroder, B. (1999), "Power and influence in the buying center", European Journal of Marketing, Vol. 33 No. 11/12, pp. 1161-1170.

Frazier, G. L. and Summers, J. O. (1984), "Interfirm influence strategies and their application within distribution channels", Journal of Marketing, Vol. 28 No. 3, pp. 43-55.

French, J. R. P. Jr. and Raven, B. H. (1959), “The bases of social power”, in Cartwright, D. (Ed.), Studies in social power, University of Michigan Press, Ann Arbor.

Garrido-Samaniego, M. J. and Gutiérrez-Cillán, J. (2004), "Determinants of influence and participation in the buying center. An analysis of Spanish industrial companies", Journal of Business and Industrial Marketing, Vol. 19 No. 5, pp. 320-336.

Gemser, G. and Leenders, M. A. (2001), "How integrating industrial design in the product development process impacts on company performance", Journal of Product Innovation Management, Vol. 18 No. 1, pp. 28-38.

Giddens, A. (1984), The constitution of society: Outline of the theory of structuration. University of California Press.

Gilliland, D. I. and Johnston, W. J. (1997), “Toward a model of business-to-business marketing communications effects", Industrial Marketing Management, Vol. 26 No. 1, pp. 15-29. 
Gordon, G. L., Schoenbachler, D. D., Kaminski, P. F. and Brouchous, K. A. (1997), "New product development: using the salesforce to identify opportunities", Journal of Business \& Industrial Marketing, Vol. 12 No. 1, pp. 33-50.

Granot, E., Brashear, T. G. and Motta, P. C. (2012), "A structural guide to in-depth interviewing in business and industrial marketing research", Journal of Business and Industrial Marketing, Vol. 27 No. 7, pp. 547-553.

Grønhaug, K. (1976), "Exploring environmental influences in organizational buying”, Journal of Marketing Research, Vol. 13 No. 3, pp. 225-229.

Harrington, R. J. and Tjan, A. K. (2008), “Transforming strategy one customer at a time", Harvard Business Review, Vol. 86 No. 3, pp. 62-72.

Howard, P. and Doyle, D. (2006), “An examination of buying centers in Irish biotechnology companies and its marketing implications", Journal of Business and Industrial Marketing, Vol. 21 No. 5, pp. 266-280.

Jackson, Jr. D. W., Keith, J. E. and Burdick, R. K. (1984), "Purchasing agents' perceptions of industrial buying center influence: A situational approach", Journal of Marketing, Vol. 48 No. 4, pp. 75-83.

Johnston, W. J. and Bonoma, T. V. (1981), “The buying center: structure and interaction patterns", Journal of Marketing, Vol. 45 No. 3, pp. 143-156.

Kauffman, R. G. (1996), "Influences on organizational buying choice processes: future research directions", Journal of Business and Industrial Marketing, Vol. 11 No. 3/4, pp. 94107.

Keszey, T. and Biemans, W. (2017), “Trust in marketing's use of information from sales: the moderating role of power", Journal of Business \& Industrial Marketing, Vol. 32 Issue: 2, pp. 258-273.

Kohli, A. K. and Zaltman, G. (1988), "Measuring multiple buying influences”, Industrial Marketing Management, Vol. 17 No. 3, pp. 197-204.

Kohli, A. K. (1989), "Determinants of influence in organizational buying: A contingency approach", Journal of Marketing, Vol 53 No. 3, pp. 50-65.

Kumar, N., Stern, L. W. and Anderson, J. C. (1993), "Conducting interorganizational research using key informants", Academy of Management, Vol. 36 No. 6, pp. 1633-1651.

Lewin, J. E. and Donthu, N. (2005), “The influence of purchase situation on buying center structure and involvement: A select meta-analysis of organizational buying behavior research", Journal of Business Research, Vol. 58 No. 10, pp. 1381-1390. 
Lilien, G. L. and Wong, A. M. (1984), “An exploratory investigation of the structure of the buying center in the metalworking industry", Journal of Marketing Research, Vol. 21 No. 1, pp. 1-11.

Martin, J. H., Daley, J. M. and Burdg, H. B. (1988), "Buying influences and perceptions of transportation services”, Industrial Marketing Management, Vol. 17 No. 4, pp. 305-314.

Mast, K. E. and Hawes, J. M. (1986), "Perceptual differences between buyers and engineers", Journal of Purchasing and Material Management, Vol. 22 No. 1, pp. 2-6.

McQuiston, D. H. (1989), "Novelty, complexity, and importance as causal determinants of industrial buyer behavior", Journal of Marketing, Vol. 53 No. 2, pp. 66-79.

Miles, M. and Huberman, M. (1984), Qualitative data analysis: A source book of new methods, Sage Publications, Newbury Park.

Min, H. and Emam, A. (2003), "Developing the profiles of truck drivers for their successful recruitment and retention: A data mining approach", International Journal of Physical Distribution and Logistics Management, Vol. 33 No. 2, pp. 149-162.

Moon, J. and Tikoo, S. (2002), "Buying decision approaches of organizational buyers and users", Journal of Business Research, Vol. 55 No. 4, pp. 293-299.

Moriarty Jr, R. T. and Spekman, R. E. (1984), “An empirical investigation of the information sources used during the industrial buying process", Journal of Marketing Research, Vol. 21 No. 2, pp. 137-147.

Mudambi, S. (2002), "Branding importance in business-to-business markets: Three buyer clusters", Industrial Marketing Management, Vol. 31 No. 6, pp. 525-533.

Naumann, E., Lincoln, D. J. and McWilliams, R. D. (1984), “The purchase of components: functional areas of influence", Industrial Marketing Management, Vol. 13 No. 2, pp. 113-122. Nicosia, F. M. and Wind, Y. (1977), "Emerging models of organizational buying processes", Industrial Marketing Management, Vol. 6 No. 5, pp. 353-369.

Pedeliento, G., Andreini, D., Bergamaschi, M. and Salo, J. (2016), "Brand and product attachment in an industrial context: The effects on brand loyalty", Industrial Marketing Management, Vol. 53, pp. 194-206.

Persson, M. and Åhlström, P. (2006), "Managerial issues in modularising complex products”, Technovation, Vol. 26 No. 11, pp. 1201-1209.

Pingry, J. R. (1974), “The engineer and purchasing agent compared", Journal of Purchasing, Vol. 10 No. 11, pp. 33-45. 
Qualls, W. J. and Rosa, J. (1995), “Assessing industrial buyers' perceptions of quality and their effects on satisfaction”, Industrial Marketing Management, Vol. 24 No. 5, pp. 359-368.

Robinson, P. J., Faris, C. W. and Wind, Y. (1967), Industrial buying and creative marketing, Allyn and Bacon, Boston.

Ronchetto, Jr., J. R., Hutt, M. D. and Reingen, P. H. (1989), "Embedded influence patterns in organizational buying systems", Journal of Marketing, Vol. 53 No. 4, pp. 51-62.

Shamdasani, P., Tat Keh, H. and Ter-Sin Chan, K. (2001), "The efficacy of power and influence strategies in a conventional channel: A Singapore perspective”, Journal of Business \& Industrial Marketing, Vol. 16 No. 1, pp. 21-38.

Sheth, J. N. (1973), “A model of industrial buyer behavior”, Journal of Marketing, Vol. 37 No. 4, pp. 50-56.

Silk, A. J. and Kalwani, M. U. (1982), "Measuring influence in organizational purchase decisions", Journal of Marketing Research, Vol. 19 No. 2, pp. 165-181.

Spekman, R. E. and Stem, L. W. (1979), "Environmental uncertainty and buying group structure: An empirical investigation”, Journal of Marketing, Vol. 43 No. 2, pp. 54-64.

Strauss, A. and Corbin, J. (1990), Basics of qualitative research: Grounded theory procedures and techniques, Sage Publications, Newbury Park.

Tanner, J. F. (1998), "Users' role in the purchase: Their influence, satisfaction, and desire to participate in the next purchase", Journal of Business and Industrial Marketing, Vol. 13 No. 6, pp. 479-491.

Taylor, G. S. (1994), "The relationship between sources of new employees and attitudes toward the job", The Journal of Social Psychology, Vol. 134 No. 1, pp. 99-110.

Töllner, A., Blut, M. and Holzmüller, H. H. (2011), "Customer Solutions in the Capital Goods Industry: Examining the Impact of the Buying Center", Industrial Marketing Management, Vol. 40 No. 5, pp. 712-722.

Torrey, F.W. IV and Murrey, D. (2014), "An Analysis of the operational costs of trucking: A 2014 update", American Transportation Research Institute. Accessible at: www.atri-online.org Venkatesh, R., Kohli, A. K. and Zaltman, G. (1995), "Influence strategies in buying centers", Journal of Marketing, Vol. 59 No. 4, pp. 71-82.

Wilson, D. F. (2000), "Why divide consumer and organizational buyer behavior?", European Journal of Marketing, Vol. 34 No. 7, pp. 780-796. 
Yamamoto, M. and Lambert, D. R. (1994), "The impact of product aesthetics on the evaluation of industrial products", Journal of Product Innovation Management, Vol. 11 No. 4, pp. 309324.

Yukl, G. A. (2002). Leadership in Organizations. Prentice Hall. 
Appendix A- Current state of knowledge about individual end-users' influence on industrial purchasing

\begin{tabular}{|c|c|c|c|c|c|}
\hline Author(s) & Aim of the study & $\begin{array}{l}\text { Type of product(s) } \\
\text { purchased }\end{array}$ & Methodology & $\begin{array}{l}\text { Buying center members } \\
\text { surveyed/interviewed* }\end{array}$ & $\begin{array}{l}\text { Findings on end-users } \\
\text { influence }\end{array}$ \\
\hline $\begin{array}{l}\text { Grønhaug } \\
\text { (1976) }\end{array}$ & $\begin{array}{l}\text { To unveil differences in buying } \\
\text { behavior of product-dependent } \\
\text { and product-independent } \\
\text { companies. }\end{array}$ & Micro-computer. & $\begin{array}{l}\text { Pilot study employing } \\
\text { semi-structured } \\
\text { personal interviews in } \\
\text { industrial buying } \\
\text { organizations + survey } \\
\text { questionnaire. }\end{array}$ & Purchasing managers. & $\begin{array}{l}\text { Users are asked for } \\
\text { advice in the suppliers' } \\
\text { search. }\end{array}$ \\
\hline $\begin{array}{l}\text { Doyle et al. } \\
\text { (1979) }\end{array}$ & $\begin{array}{l}\text { To investigate the relationship } \\
\text { between buying classes and } \\
\text { buying phases, and to unveil } \\
\text { differences in the composition } \\
\text { and size of buying centers in } \\
\text { straight rebuy, modified rebuy, } \\
\text { and new-task buying situations. }\end{array}$ & $\begin{array}{l}\text { Raw materials, steel tubing, } \\
\text { industrial glass components, } \\
\text { tile adhesive, hydrated lime, } \\
\text { cement, computer output } \\
\text { forms, computer sequence } \\
\text { controllers, decanting } \\
\text { centrifuges, remote control } \\
\text { and monitoring systems, } \\
\text { automatic packaging } \\
\text { machines, research and } \\
\text { development services, air- } \\
\text { brake actuators, and brake } \\
\text { seals. }\end{array}$ & Personal interviews. & $\begin{array}{l}\text { Senior marketing managers of } \\
\text { British industrial companies. }\end{array}$ & $\begin{array}{l}\text { Firms operating in } \\
\text { straight rebuy situations } \\
\text { reported that the user in } \\
\text { the customer firm often } \\
\text { initiated the need to buy. } \\
\text { Users are often involved } \\
\text { with the purchasing agent } \\
\text { in evaluating alternative } \\
\text { products in all cases of } \\
\text { straight re-buys. Product } \\
\text { user may make the initial } \\
\text { contact in new-task } \\
\text { buying situations. }\end{array}$ \\
\hline $\begin{array}{l}\text { Bellizzi } \\
\text { (1979) }\end{array}$ & $\begin{array}{l}\text { To identify the relative influence } \\
\text { of buying center members in } \\
\text { different phases of the buying } \\
\text { process and for four different } \\
\text { type of purchasing. }\end{array}$ & $\begin{array}{l}\text { Four different type of } \\
\text { construction equipment and } \\
\text { materials purchasing: } \\
\text { capital goods (e.g., cranes), } \\
\text { accessory equipment (e.g., } \\
\text { power tools), major } \\
\text { materials (e.g., cement), and } \\
\text { operating supplies (e.g., } \\
\text { nails). }\end{array}$ & Survey questionnaire. & $\begin{array}{l}\text { Top managers, construction } \\
\text { site superintendents, architects } \\
\text { and consulting engineers, } \\
\text { purchasing agents, company } \\
\text { engineers, shop foremen and } \\
\text { other building trade } \\
\text { workers. }\end{array}$ & $\begin{array}{l}\text { Shop foremen and other } \\
\text { building trade workers } \\
\text { exert influence on } \\
\text { purchase of equipment } \\
\text { accessories, operating } \\
\text { supplies, and major } \\
\text { capital goods. They have } \\
\text { no influence on the } \\
\text { purchase of capital } \\
\text { equipment. }\end{array}$ \\
\hline $\begin{array}{l}\text { Silk and } \\
\text { Kalwani } \\
(1982)\end{array}$ & $\begin{array}{l}\text { To identify the structure of } \\
\text { buying groups. }\end{array}$ & Lithographic plates. & $\begin{array}{l}\text { A pilot study of } 25 \\
\text { printing firms, } \\
\text { structured interviews. }\end{array}$ & $\begin{array}{l}\text { General managers, } \\
\text { foremen/supervisor, plate- } \\
\text { makers, and pressmen. }\end{array}$ & $\begin{array}{l}\text { The role of users is } \\
\text { essential in initiating } \\
\text { changes but diminished in } \\
\text { evaluating alternatives }\end{array}$ \\
\hline
\end{tabular}




\begin{tabular}{|c|c|c|c|c|c|}
\hline & & & & & $\begin{array}{l}\text { and making a final } \\
\text { decision. }\end{array}$ \\
\hline $\begin{array}{l}\text { Moriarty and } \\
\text { Speckman } \\
(1984)\end{array}$ & $\begin{array}{l}\text { To investigate the sources of } \\
\text { information sought by buyers } \\
\text { during the industrial buying } \\
\text { process. To examine the factors } \\
\text { that help explain why certain } \\
\text { information sources are used } \\
\text { during the buying process. }\end{array}$ & Dumb data terminal & Survey questionnaire. & $\begin{array}{l}\text { Information systems } \\
\text { department members, top } \\
\text { management, using } \\
\text { department members, } \\
\text { terminal users, external } \\
\text { consultants, colleagues, } \\
\text { purchasing department } \\
\text { members. }\end{array}$ & $\begin{array}{l}\text { Findings reveal that users } \\
\text { are influential, as they are } \\
\text { recognized as experts in } \\
\text { using the specific type of } \\
\text { product to be purchased. } \\
\text { Users have a significant } \\
\text { role during the search for } \\
\text { alternative vendors. }\end{array}$ \\
\hline $\begin{array}{l}\text { Jackson et al. } \\
\text { (1984) }\end{array}$ & $\begin{array}{l}\text { To assess the relative influence } \\
\text { of participant changes across } \\
\text { purchases of different product } \\
\text { types, buy classes, and two } \\
\text { different decision types, namely, } \\
\text { determination of the product to } \\
\text { buy and selection of the supplier. }\end{array}$ & $\begin{array}{l}\text { Major capital, minor capital, } \\
\text { materials, components, and } \\
\text { supplies in several } \\
\text { industries: electronics, } \\
\text { aerospace, computers, } \\
\text { transportation, energy } \\
\text { production, } \\
\text { pharmaceuticals, consumer } \\
\text { products, paper, } \\
\text { Communications }\end{array}$ & Survey questionnaire. & $\begin{array}{l}\text { Respondents were from the } \\
\text { following departments: } \\
\text { purchasing (the only group } \\
\text { surveyed), manufacturing, } \\
\text { engineering, top management } \\
\text { and other (users). }\end{array}$ & $\begin{array}{l}\text { The influence that users } \\
\text { play is quite high in the } \\
\text { decision of what product } \\
\text { to buy in the supplies } \\
\text { category. In terms of } \\
\text { supplier selection, their } \\
\text { influence was almost null, } \\
\text { except for supplies, where } \\
\text { their expertise was } \\
\text { considered higher than } \\
\text { that of the top managers. }\end{array}$ \\
\hline $\begin{array}{l}\text { Lilien and } \\
\text { Wong (1984) }\end{array}$ & $\begin{array}{l}\text { To assess the involvement or } \\
\text { noninvolvement of different } \\
\text { buying center members in } \\
\text { different phases of the purchasing } \\
\text { decision process and across } \\
\text { different product categories. }\end{array}$ & Metalworking products & Survey questionnaire. & $\begin{array}{l}\text { Corporate management or } \\
\text { proprietorship production and } \\
\text { engineering personnel, } \\
\text { purchasing agents. }\end{array}$ & $\begin{array}{l}\text { Production and } \\
\text { engineering personnel are } \\
\text { more involved in earlier } \\
\text { phases of the decision } \\
\text { process (determining type } \\
\text { and drawing up } \\
\text { specifications), while } \\
\text { purchasing agents and } \\
\text { managers are more } \\
\text { involved in the later } \\
\text { phases (selecting supplier } \\
\text { and determining amount). }\end{array}$ \\
\hline $\begin{array}{l}\text { Martin et al. } \\
\text { (1988) }\end{array}$ & $\begin{array}{l}\text { To compare the perceptions and } \\
\text { preferences of buying center role }\end{array}$ & Transportation mode & Survey questionnaire. & Buyers and users. & $\begin{array}{l}\text { Failed to validate } \\
\text { differences between }\end{array}$ \\
\hline
\end{tabular}




\begin{tabular}{|c|c|c|c|c|c|}
\hline & $\begin{array}{l}\text { groups for transportation mode } \\
\text { selection. }\end{array}$ & & & & $\begin{array}{l}\text { buyers and users. For } \\
\text { both groups, core service } \\
\text { attributes were considered } \\
\text { as the most important } \\
\text { ones. }\end{array}$ \\
\hline $\begin{array}{l}\text { McQuiston } \\
\text { (1989) }\end{array}$ & $\begin{array}{l}\text { To propose and test a model in } \\
\text { which novelty, complexity, and } \\
\text { importance are considered causal } \\
\text { determinants of participation and } \\
\text { influence in an industrial } \\
\text { purchase decision. }\end{array}$ & $\begin{array}{l}\text { Capital equipment } \\
\text { purchases by multiple } \\
\text { clients working in several } \\
\text { industries. }\end{array}$ & Survey questionnaire. & $\begin{array}{l}\text { Purchasing personnel, plant } \\
\text { management personnel, } \\
\text { engineering personnel, } \\
\text { operations personnel. }\end{array}$ & $\begin{array}{l}\text { Engineer and operations } \\
\text { personnel were found to } \\
\text { be significant influencers } \\
\text { in the purchasing process } \\
\text { of capital equipment. In } \\
\text { general the findings show } \\
\text { that as novelty and } \\
\text { importance to the } \\
\text { purchasing organization } \\
\text { rise, more information is } \\
\text { sought by members of the } \\
\text { decision-making unit } \\
\text { (including users). }\end{array}$ \\
\hline $\begin{array}{l}\text { Yamamoto } \\
\text { and Lambert } \\
(1994)\end{array}$ & $\begin{array}{l}\text { To provide evidence that the } \\
\text { appearance of an industrial } \\
\text { product may have an impact on } \\
\text { its evaluation. }\end{array}$ & $\begin{array}{l}\text { Seven product categories: } \\
\text { small gear motors, small DC } \\
\text { motors, precision dispense } \\
\text { pumps, solenoid valves, } \\
\text { stepper motor controllers, } \\
\text { oscilloscopes, and } \\
\text { multimeters. }\end{array}$ & $\begin{array}{l}\text { Conjoint scaling of } \\
\text { product attributes with } \\
\text { multiple regression } \\
\text { tests. }\end{array}$ & $\begin{array}{l}\text { Engineers, marketing } \\
\text { personnel, and purchasing } \\
\text { personnel. }\end{array}$ & $\begin{array}{l}\text { Findings show that users } \\
\text { (engineers) respond more } \\
\text { strongly to appearance } \\
\text { than the other groups, i.e., } \\
\text { marketing and purchasing } \\
\text { personnel. }\end{array}$ \\
\hline $\begin{array}{l}\text { Tanner } \\
(1998)\end{array}$ & $\begin{array}{l}\text { To investigate whether users are } \\
\text { more are more likely than non- } \\
\text { users to initiate the purchase and } \\
\text { to be more influential in early } \\
\text { phases of the process. To assess } \\
\text { whether users who participate are } \\
\text { more satisfied with the decision } \\
\text { process and with the product } \\
\text { purchased than users who did not } \\
\text { participate in the buying }\end{array}$ & Mid-range copiers. & Survey questionnaire. & $\begin{array}{l}\text { Users and non-users who are } \\
\text { influential in the purchasing } \\
\text { process. }\end{array}$ & $\begin{array}{l}\text { Users emerged as key } \\
\text { influential actors over the } \\
\text { decision of a mid-range } \\
\text { copier purchase. } \\
\text { Influence for users is } \\
\text { greater than for non-users } \\
\text { at every stage except for } \\
\text { making the final decision } \\
\text { and setting the budget. } \\
\text { Users who participated in }\end{array}$ \\
\hline
\end{tabular}




\begin{tabular}{|c|c|c|c|c|c|}
\hline & $\begin{array}{l}\text { decision. To evaluate whether } \\
\text { users rate product performance as } \\
\text { more important than do non-users } \\
\text { and whether users desire greater } \\
\text { next purchase participation than } \\
\text { non-users. }\end{array}$ & & & & $\begin{array}{l}\text { the purchase are more } \\
\text { likely to participate in the } \\
\text { next purchase than users } \\
\text { who did not participate in } \\
\text { this purchase, whereas the } \\
\text { non-users were in general } \\
\text { more likely to want to } \\
\text { participate. }\end{array}$ \\
\hline $\begin{array}{l}\text { Dadzie et al. } \\
\text { (1999) }\end{array}$ & $\begin{array}{l}\text { To explore the structure of the } \\
\text { buying center for logistics } \\
\text { automation technologies. To } \\
\text { examine the relationships } \\
\text { between the degrees of } \\
\text { participation of key functional } \\
\text { areas, the extent of coalescence } \\
\text { on buying decision criteria, and } \\
\text { the rate of adoption. }\end{array}$ & $\begin{array}{l}\text { Logistics automation } \\
\text { technologies. }\end{array}$ & Survey questionnaire. & $\begin{array}{l}\text { Senior management, finance, } \\
\text { RandD, engineering, } \\
\text { manufacturing, purchasing, } \\
\text { logistics, management, others. }\end{array}$ & $\begin{array}{l}\text { Users were found to be } \\
\text { the most active } \\
\text { participants in the } \\
\text { organizational buying } \\
\text { decision process of } \\
\text { logistics automation } \\
\text { technologies. Users did } \\
\text { not consider equipment } \\
\text { cost as critical as service } \\
\text { availability and customer } \\
\text { service improvements. } \\
\text { For users service levels } \\
\text { precede cost } \\
\text { considerations. Non-users } \\
\text { instead are more sensitive } \\
\text { to prices. }\end{array}$ \\
\hline $\begin{array}{l}\text { Moon and } \\
\text { Tikoo (2002) }\end{array}$ & $\begin{array}{l}\text { To compare buying activities, the } \\
\text { accompanying prototypical } \\
\text { buying decision approaches, and } \\
\text { the impact of situational variables } \\
\text { on the use of a buying decision } \\
\text { approach by organizational } \\
\text { buyers and users. }\end{array}$ & $\begin{array}{l}\text { Equipment (e.g., X-ray } \\
\text { machines), surgical tools, } \\
\text { patient beds, } \\
\text { medical supplies (e.g., } \\
\text { bandages, gloves), and } \\
\text { dental materials (e.g., gold, } \\
\text { amalgam). }\end{array}$ & Survey questionnaire. & $\begin{array}{l}\text { Purchasing executives/ } \\
\text { administrative officers in } \\
\text { charge of purchasing (buyers), } \\
\text { doctors (users). }\end{array}$ & $\begin{array}{l}\text { Users are influential. } \\
\text { They are influential } \\
\text { especially in those cases } \\
\text { in which expert's advice } \\
\text { are needed. Thus users } \\
\text { are more influential in } \\
\text { new task buy, modified } \\
\text { rebuy, and straight rebuy. }\end{array}$ \\
\hline Albert (2003) & $\begin{array}{l}\text { To adapt a microsegment } \\
\text { model to an industrial setting; to } \\
\text { define the buying motives and } \\
\text { benefits sought by segments in a } \\
\text { complex, }\end{array}$ & $\begin{array}{l}\text { Steel-made products for } \\
\text { concrete reinforcement in } \\
\text { the construction industry. }\end{array}$ & Survey questionnaire. & $\begin{array}{l}\text { Steel manufacturers, } \\
\text { intermediaries (pre-casters, } \\
\text { fabricators, and distributors) } \\
\text { and end-users (structural } \\
\text { engineers, architects, }\end{array}$ & $\begin{array}{l}\text { The more end users } \\
\text { occupy an upstream } \\
\text { position in the supply } \\
\text { chain, the more technical } \\
\text { information and technical }\end{array}$ \\
\hline
\end{tabular}




\begin{tabular}{|c|c|c|c|c|c|}
\hline & $\begin{array}{l}\text { commodity type industry; to } \\
\text { develop specialized integrated } \\
\text { communication strategies based } \\
\text { on the need-based segments. }\end{array}$ & & & $\begin{array}{l}\text { department of } \\
\text { transportation, contractors). }\end{array}$ & $\begin{array}{l}\text { product features are } \\
\text { relevant criteria for } \\
\text { guiding the purchasing } \\
\text { process. In contrast, the } \\
\text { end-users occupy a } \\
\text { downstream position in } \\
\text { the supply chain (such as } \\
\text { contractors), the more } \\
\text { commercial aspects (e.g. } \\
\text { prices and discounts) } \\
\text { become salient. }\end{array}$ \\
\hline $\begin{array}{l}\text { Garrido- } \\
\text { Samaniego } \\
\text { and } \\
\text { Gutiérrez- } \\
\text { Cillán (2004) }\end{array}$ & $\begin{array}{l}\text { To propose a causal model in } \\
\text { which the characteristics of the } \\
\text { buying situation, } \\
\text { the personal } \\
\text { characteristics of the individual } \\
\text { and the characteristics of the } \\
\text { organizational structure } \\
\text { determine the level of } \\
\text { participation in the buying center } \\
\text { and the distribution of power. }\end{array}$ & $\begin{array}{l}\text { Capital equipment and } \\
\text { office supplies purchases. }\end{array}$ & Survey questionnaire. & $\begin{array}{l}\text { Purchasing directors of firms } \\
\text { operating in different } \\
\text { industries. }\end{array}$ & $\begin{array}{l}\text { The influential role of } \\
\text { users changes according } \\
\text { to the type of product to } \\
\text { purchase: the } \\
\text { manufacturing and } \\
\text { engineering users in the } \\
\text { case of capital equipment, } \\
\text { and administrative users } \\
\text { in the case of office } \\
\text { supplies. }\end{array}$ \\
\hline $\begin{array}{l}\text { Howard and } \\
\text { Doyle (2006) }\end{array}$ & $\begin{array}{l}\text { To examine key influencers, as } \\
\text { well as to examine } \\
\text { the decision process. }\end{array}$ & $\begin{array}{l}\text { Product purchasing in the } \\
\text { biotechnology industry } \\
\text { Different kind of purchases } \\
\text { including power electricity, } \\
\text { fermenter for production } \\
\text { purposes, surgical gloves, } \\
\text { and technologies. }\end{array}$ & $\begin{array}{l}\text { Multiple case studies, } \\
\text { qualitative interviews } \\
\text { to key informants. }\end{array}$ & $\begin{array}{l}\text { Multiple informants from } \\
\text { multiple firms' functions and } \\
\text { divisions. It is not clear if users } \\
\text { were interviewed as } \\
\text { informants. }\end{array}$ & $\begin{array}{l}\text { Users were found to be } \\
\text { key influencers in the } \\
\text { decision process. The role } \\
\text { played by end users was } \\
\text { found to be particularly } \\
\text { relevant because of their } \\
\text { expertise for specific } \\
\text { purchases. However, } \\
\text { users are rarely in charge } \\
\text { for guiding the whole } \\
\text { decision making process. }\end{array}$ \\
\hline $\begin{array}{l}\text { Harrington } \\
\text { and Tjan } \\
(2008)\end{array}$ & $\begin{array}{l}\text { To provide an example of a } \\
\text { company that was successful by } \\
\text { targeting its marketing efforts }\end{array}$ & $\begin{array}{l}\text { Information management } \\
\text { systems for press agencies. }\end{array}$ & Case study. & $\begin{array}{l}\text { Ethnographic observation of } \\
\text { end users. Interviews with end } \\
\text { users. }\end{array}$ & $\begin{array}{l}\text { They show how the } \\
\text { company was able to } \\
\text { increase revenues and }\end{array}$ \\
\hline
\end{tabular}




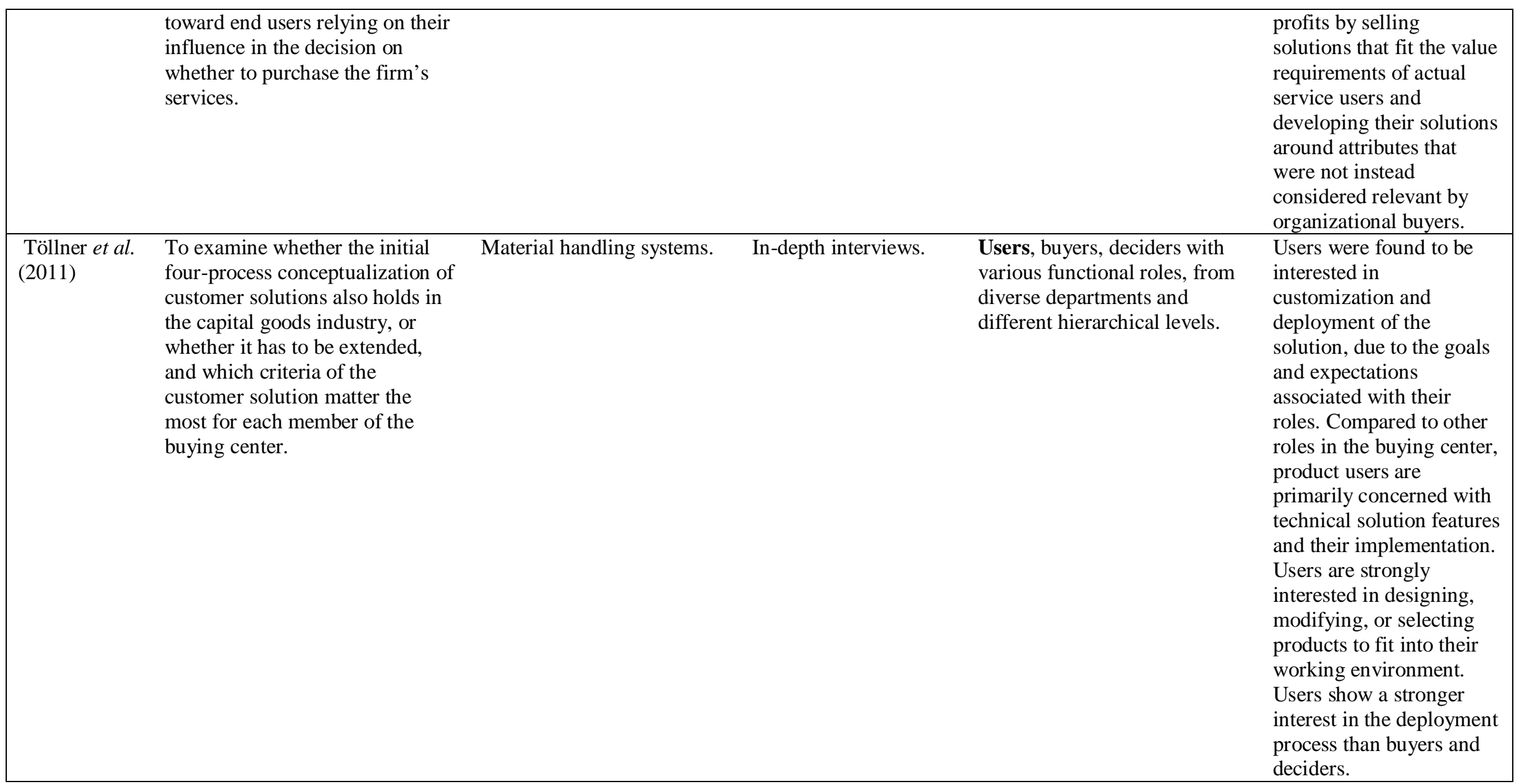

* When not explicitly indicated as end users, end users are distinguished from other organizational actors by the use of bold font. 
APPENDIX B - Buyers and users interviewed

\begin{tabular}{clc} 
Buyers & Type of transportation & Interviewee \\
\hline & General hauling & Company owner \\
& Industrial products, healthcare appliances & Company owner \\
Micro-firms (1-3 trucks) & Steel products, marble and other construction raw materials & Company owner \\
& Materials and equipment for constructions & Company owner \\
& Glass bottles for water companies & Company owner \\
& Furniture & Company owner \\
\hline & Metal and other ferrous materials & Company owner \\
& General hauling and retail distribution & Company owner \\
& Industrial and hazardous waste & Company owner \\
& Drinkable water & Company owner \\
& General hauling & Company owner \\
& Construction materials & Company owner \\
\hline \multirow{3}{*}{ Small-firms (4-10 trucks) } & Industrial products, elevators, agricultural equipments, tires & Head of purchasing \\
& General hauling, steel, wood, paper & Company owner \\
& Paper, industrial equipments, steel and other ferrous materials & Company owner \\
& Concrete & Company owner \\
& General hauling & Company owner \\
& Steel and other ferrous materials & Company owner \\
\hline \multirow{3}{*}{ Medium firms (11-50 trucks) } & Logistics and transportation & Head of purchasing \\
& General hauling, construction materials, bulk transportation & Company owner \\
& Transportation and logistic for retailers & Company owner \\
& Transportation and logistic for retailers & Company owner \\
& Transportation and logistic for terminal containers & Company owner \\
& General hauling & Company owner \\
\hline & &
\end{tabular}




\begin{tabular}{llc} 
End Users & Type of transportation & Brand driven \\
\hline & Food distribution & Scania \\
& Steel made products (in-house transportation) & Mercedes \\
Micro-firms (1-3 trucks) & Steel made products (in-house transportation) & Mercedes \\
& General hauling & Mercedes \\
& Paper made products & Volvo \\
& Wood and wood made products & Man \\
\hline & General hauling & Mercedes/Scania \\
& General hauling & Mercedes \\
& Construction materials & Scania \\
& General hauling & Iveco \\
& General hauling & Iveco \\
& Construction materials & Mercedes \\
\hline & General hauling and retail distribution & Iveco \\
& General hauling & Mercedes \\
& Polypropylene and polystyrene (in-house transportation) & Iveco \\
& Roadside assistance and general hauling & Man \\
& General hauling & Iveco \\
& General hauling & Daf \\
\hline \multirow{3}{*}{ Medium firms (11-50 trucks trucks) } & General hauling & Man \\
& Logistics and transportation & Iveco \\
& General hauling & Scania \\
& General hauling & Volvo \\
& Chemical products & Daf \\
& Pharmaceutical products & Daf \\
\hline & &
\end{tabular}


